\title{
Surgical Techniques for Inferior Turbinate Reduction: Is there an Exit from the Labyrinth?
}

\author{
Luca D'Ascanio ${ }^{1 *}$, Stefano Cantore ${ }^{2}$ and Fabio Piazza ${ }^{1}$ \\ ${ }^{1}$ Department of Otolaryngology - Head \& Neck Surgery, Carlo Poma Civil Hospital, Italy \\ ${ }^{2}$ Department of Otolaryngology - Head \& Neck Surgery, Sant'Orsola-Malpighi Hospital, Italy
}

Submission: March 28, 2016; Published: April 03, 2017

*Corresponding author: Luca D’Ascanio, Department of Otolaryngology - Head \& Neck Surgery, “Carlo Poma” Civil Hospital, Strada Lago Paiolo, 10 - 46100 Mantova, Italy, Tel : +39 3283186967; Fax: +39 0854214566; Email: l.dascanio@gmail.com

Keyword: Editorial; Surgical techniques; Inferior turbinate

\section{Editorial}

Chronicnasalobstruction can significantlyimpairpatients'life quality and is a frequent complaint reported to Otolaryngologists. Inferior turbinate hypertrophy (ITH) is a common cause of nasal breathing impairment.1 Various etiologies for ITH have been reported such as allergic reactions, nonallergic rhinitis, chronic hypertrophic rhinitis, and compensatory hypertrophy in case of septal deviations. Numerous surgical techniques have been described to reduce the size of the inferior turbinates: partial or total turbinectomy, electrocautery, cryotherapy, laser cautery, submucosal resection, submucosal turbinate bone resection, turbinoplasties with turbinate lateral displacement, radiofrequency-assisted turbinoplasty, microdebrider-assisted turbinoplasty, and ultrasound turbinate reduction [1-8].

Despite the amount of surgical techniques described, there is no definite consensus as to which surgical approach is most effective to treat ITH and especially young Otolaryngologists may find it extremely difficult to orientate themselves in this "labyrinth" of techniques. Passali et al. [1] reported the superiority of submucosal resection combined with lateral displacement over other techniques (turbinectomy, laser cautery, electrocautery, cryotherapy) to attain long-term improvement of nasal obstruction due to ITH. The U.S. Food and Drug Administration approved radiofrequency volumetric tissue reduction for the treatment of airway obstruction in 1998. After its approval, investigators reported the efficacy of radiofrequency submucosal volumetric tissue reduction for the treatment of ITH [2]. Microdebrider-assisted inferior turbinoplasty was introduced in the late 1990s as another mucosa-preservation technique. Several authors $[3,4]$ published the longer duration of improvement in nasal obstructive symptoms obtained with microdebrider treatment with respect to the radiofrequency one.

The use of ultrasound treatment of hypertrophied inferior turbinates, as another submucosal treatment, has been investigated as well [5]. Again, some authors published on the superiority of ultrasound turbinate reduction with respect to radiofrequency ablation and electrocautery. The plethora of publications on the surgical treatment of ITH seems to show that any technology or device developed for surgery is (and will probably be) applied to turbinate surgery [6-8]. Therefore, no definite "exit from the labyrinth" of surgical techniques for ITH seems to exist. A part from turbinectomy, which has been abandoned because of the risks of empty nose syndrome, bleeding and persistent nasal crusting, [9] all the other techniques have their own pros and cons.

The main advantage of hot instruments over traditional cold one is represented by the absence of bleeding, which may represent a relevant complication after turbinate cold surgery (especially when it is associated with other procedures, such as rhinoplasty or endoscopic sinus surgery). Mucosal sparing techniques with lateral displacement of the inferior turbinate have proved to be effective, even though other techniques (i.e. electocautery) can be useful in severe edema/polypoid degeneration of the inferior turbinate mucosa. In such cases, mucosal sparing techniques may be unable to attain a significant resolution of turbinate disease, though endonasal crusting (often solvable with few days of saline nasal washings) usually develops. Even though technical equipment is constantly developing, the basic surgical principles should be kept in mind. 
Our lifetime experience has taught us that when several techniques are used to face the same problem, either all of them are efficacious or none of them allows solving it. Most of the literature seems to confirm all the proposed techniques are successful in managing ITH [10]. In addition, the high cost of new equipment should also be considered in relation to the low complexity and low reimbursement of turbinate surgery in most modern Health Care Systems [11]. Considering the efficacy of most of the ITH surgical approaches in terms of turbinate decongestion, the easiest, cheapest and most straightforward technique is probably the one to be preferred.

\section{References}

1. Passali D, Passali G, Damiani V, Bellussi L (2003) Treatment of inferior turbinate hypertrophy: a randomized clinical trial. Ann Otol Rhinol Laryngol 112(8): 683-688.

2. Nease CJ, Krempl GA (2004) Radiofrequency treatment of turbinate hypertrophy: a randomized, blinded, placebo-controlled clinical trial. Otolaryngol Head Neck Surg 130(3): 291-299.

3. Liu CM, Tan CD, Lee FP, Lin KN, Huang HM (2009) Microdebriderassisted versus radiofrequency-assisted inferior turbinoplasy. Laryngoscope 119(2): 414-418.

4. Cingi C, Ure B, Cakli E, Ozudogru E (2010) Microdebrider-assisted versus radiofrequency- assisted inferior turbinoplasty: a prospective study with objective and subjective outcome measures. Acta Otorhinolaryngol Ital 30: 138-143.

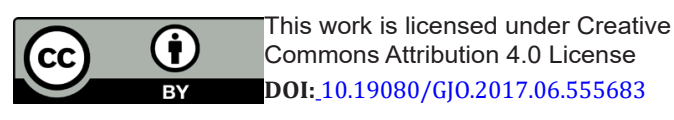

5. Gindros G, Kantas I, Balatsouras D, Kaidoglou A, Kandiloros D (2010) Comparison of ultrasound turbinate reduction, radiofrequency tissue ablation and submucosal cauterization in inferior turbinate hypertrophy. Eur Arch Otorhinolaryngol 267(11): 1727-1733.

6. Dhulipalla S (2015) Comparative study of response through reduction in the size of hypertrophied inferior turbinate causing nasal obstruction by different surgical modalities: a prospective study. Indian J Otolaryngol Head Neck Surg 67(1): 56-59.

7. Passali D, Loglisci M, Politi L, Passali GC, Kern E (2016) Managing turbinate hypertrophy: coblation vs. radiofrequency treatment. Eur Arch Otorhinolaryngol 273(6): 1449-1453.

8. Uluyol S, Karakaya NE, Gur MH, Kilicaslan S, Kantarcioglu EO, et al. (2016) Radiofrequency Thermal Ablation versus Bipolar Electrocautery for the Treatment of Inferior Turbinate Hypertrophy: Comparison of Efficacy and Postoperative Morbidity. Int Arch Otorhinolaryngol 20(1): 2-5.

9. Leong SC (2015) The clinical efficacy of surgical interventions for empty nose syndrome: A systematic review. Laryngoscope 125(7): 1557-1562.

10. Prokopakis EP, Koudounarakis EI, Velegrakis GA (2014) Efficacy of inferior turbinoplasty with the use of CO (2) laser, radiofrequency, and electrocautery. Am J Rhinol Allergy 28(3): 269-272.

11. Thomas A, Alt J, Gale C, Vijayakumar S, Padia R, et al. (2016) Surgeon and hospital cost variability for septoplasty and inferior turbinate reduction. Int Forum Allergy Rhinol 6(10): 1069-1074.

\section{Your next submission with Juniper Publishers will reach you the below assets}

- Quality Editorial service

- Swift Peer Review

- Reprints availability

- E-prints Service

- Manuscript Podcast for convenient understanding

- Global attainment for your research

- Manuscript accessibility in different formats

( Pdf, E-pub, Full Text, Audio)

- Unceasing customer service

Track the below URL for one-step submission https://juniperpublishers.com/online-submission.php 